\title{
ДОКАЗОВА ФАРМАЦІЯ: ЛІКАРСЬКІ ФІТОПРЕПАРАТИ ДЛЯ ОНКОЛОГІЇ НА ОСНОВІ ТАКСАНІВ, ПРОТИПУХЛИННИХ ДИТЕРПЕНІВ TAXUS BACCATA L.
}

\section{EVIDENCE-BASED PHARMACY: TAXANES BASED ANTITUMOR DITERPENES OF TAXUS BACCATA L. HERBAL MEDICINAL PRODUCTS FOR ONCOLOGY}

\author{
Alina Osyntseva ${ }^{1}$ (PhD in Pharmaceutical Sciences), \\ Anatolii Derkach ${ }^{1}$ (PhD in Pharmaceutical Sciences, \\ Associate Professor), Serhii Negretskii ${ }^{1}$ (PhD in \\ Pharmaceutical Sciences) \\ ${ }^{1}$ Kharkiv Medical Academy of Postgraduate Education, \\ Kharkiv, Ukraine \\ *Corresponding author: Alina Osyntseva
} Received: January 19, 2022

Abstract. Creating of new effective, safe, high-quality and cost-effective drugs for cancer patients is important for scientists. In recent years, herbal medicines have been widely used in the pharmacotherapy of cancer. The world is conducting research among substances of natural origin in terms of determining non-traditional effects on tumor growth. The aim of the study was to study medicinal phytopreparations for oncology based on taxanes, antitumor diterpenes of Taxus Baccata L. from the position of evidence-based pharmacy. Taxanes have been shown to be promising in cancer pharmacotherapy. Pharmacological studies of taxanes isolated from the "foot" of Taxus Baccata L. were described. The results of the study of potential anticancer agents based on the diterpenoid taxane skeleton have been established. It has been proven to increase the effectiveness of pharmacotherapy of operable breast cancer with the inclusion of taxanes in adjuvant and non-adjuvant chemotherapy.

Keywords: evidence-based pharmacy, cancer, pharmacotherapy, anticancer drugs, herbal raw materials, taxanes.

Вступ. В сучасних умовах у світі зростає небезпечність поширення гострої респіраторної хвороби COVID-19, спричиненої коронавірусом SARS-CoV-2 [1, 

2]. Складність та невирішеність багатьох проблем, пов'язаних з організацією обігу лікарських засобів (ЛЗ) та їх доступністю для пацієнтів, фармакотерапією найбільш поширених хвороб суспільства на тлі коморбідних розладів в умовах пандемії COVID-19, обумовлюють необхідність пошуку нових безпечних та ефективних Л3 [3-6]. Раніше вітчизняними вченими було доведено ефективність, безпечність та доступність ЛЗ на основі лікарської рослинної сировини [7-10]. Численні публікації свідчать про зростання онкологічної захворюваності, нові методики лікування в області кардіоонкології, онкомамології, пухлин голови та шиї, онкоурології, меланоми, колоректального раку, онкоімунології, онкогематології, онкогінекології, застосування променевої терапії. Актуальністю організаційно-правових досліджень обігу та доступності ЛЗ для онкохворих займалися вітчизняні вчені [11-13]. Станом на початок 2021 р. в Україні на обліку в медичних установах перебувало 1 млн 187,6 тисяч пацієнтів 3 онкологічними захворюваннями [14]. За даними фахівців Міжнародного агентства з вивчення раку, у 2020 р. захворюваність на рак в 185 країнах мала такі тенденції [15]:

> кількість нових випадків досягла 19,3 мільйона громадян;

$>\quad$ кількість летальних випадків - 10 млн чоловік;

$>\quad$ перше місце в епідеміології займає рак молочної залози (кожний восьмий новий випадок раку в світі і кожний четвертий - серед жінок);

> на другому місці - рак легенів і рак прямої кишки;

$>\quad$ онкологічне захворювання діагностується у кожного п'ятого громадянина світу протягом життя;

$>\quad$ летальні випадки спостерігаються у кожного восьмого чоловіка і кожної 11 жінки;

$>\quad$ число щорічних нових випадків (до 2040 р.) онкологічних захворювань може зрости на 47 відсотків;

$>$ фактори ризику, що впливають на онкозахворюваність - паління, наркотична та алкогольна залежність, нездорове харчування, ожиріння та малорухомий спосіб життя. 
SSP Modern Pharmacy and Medicine (ISSN 2733-368X), Volume 2 Issue 1, Jan-Mar 2022

Відповідно до Національної стратегії контролю онкологічних захворювань до 2030 р., МО3 України необхідно забезпечити доступність для пацієнтів основних та допоміжних ЛЗ (хіміотерапія, гормональна та біологічна терапія) [16].

Створення нових ефективних, безпечних, якісних та економічно доступних ЛЗ для онкохворих є актуальним для науковців [17-20]. В останні роки у фармакотерапії онкологічних захворювань знайшли широке використання ЛЗ рослинного походження. У світі проводяться дослідження серед речовин природнього походження в плані визначення нетрадиційних впливів на пухлинний ріст.

Метою роботи було вивчення лікарських фітопрепаратів для онкології на основі таксанів, протипухлинних дитерпенів Taxus Baccata L. на основі доказової фармації.

Матеріали та методи. Інформаційно-аналітичну основу дослідження склали наукові праці за темою роботи. Зазначимо, що огляд наукових джерел літератури було проведено із врахуванням рекомендацій Кокрейнівського товариства за PICO: P (population) - населення, що страждає на онкологічні розлади здоров'я; I (intervention) - медицина, фармація, фармакотерапія, ефективні, безпечні, доступні ліки; С (comparator) - технологія дослідження; О (outcomes) - результати дослідження. В якості методів дослідження використано нормативно-правовий, документальний, ретроспективний, порівняльний, системний, табличний, судово-фармацевтичний та графічний. Для обробки результатів, визначення узгодженості між досліджуваними параметрами використано програму Microsoft Excel 2010 (описові характеристики: мінімальне та максимальне значення, середнє значення).

Дослідження статті є фрагментом науково-дослідних робіт Харківської медичної академії післядипломної освіти за темами «Удосконалення організаційно-правової процедури забезпечення ліками пацієнтів 3 позиції судової фармації, організації і управління фармацією» (номер державної реєстрації 0116U003137, термін виконання 2016-2020рр.) та «Фармацевтичне та 
SSP Modern Pharmacy and Medicine (ISSN 2733-368X), Volume 2 Issue 1, Jan-Mar 2022 медичне право: інтегровані підходи до системи обігу ліків з позиції судової фармації та організації фармацевтичної справи» (номер державної реєстрації 0121 U000031, термін виконання 2021-2026 рр.).

Результати та ї обговорення. Таксани можуть призначатися у паліативному лікуванні та вважаються перспективними у фармакотерапії раку. 3 метою пошуку нових цитостатичних препаратів в 1971 р. Національним раковим інститутом США були проведені перші випробування екстракту з кори тису тихоокеанського, які виявили його ефективність відносно різних штамів лейкозів, сарком, карциносарком, раку легенів. Екстракти 3 тису володіють цитотоксичною дією. Як показали дослідження, активним інгредієнтом екстракту кори тису є складний дитерпен - таксол. Таксол на відміну від вінкаалкалоїдів, які викликають деполімерізацію тубуліна мікротрубочок, індукує їх полімерізацію з утворенням стабільних нефункціональних трубочок [21-28].

Серйозною проблемою впровадження препаратів на основі тису тихоокеанського є сировинна база. Тис тихоокеанський є реліктовою рослиною, а запаси його обмежені. Тому фірмою Bristol Myers Squibb був синтезований таксол i випускається препарат під комерційною назвою «паклітаксел» (paclitaxel, NSC 125973). Продовжуючи пошук доступних джерел таксола фірмою Rone Poulenc Rorer був синтезований свій препарат - «доцетаксель» (docetaxel; міжнародна незапатентована назва - «таксотер» taxotere, RP 56976, NSC 628503) [29-34].

Найбільш імовірним розв'язанням завдання щодо пошуку вітчизняного фітопрепарату для онкології на основі таксанів є створення достатньої рослинної сировинної бази. У цьому плані становить інтерес сировина України, що представлена тисом ягідним (Taxus baccata L.) (Рис.1). Україна має у своєму розпорядженні природні популяції тису ягідного в горах Прикарпаття, Карпатах і Криму.

У літературі описано різні частини (хвоя, кора, деревина й молоді «лапки») тису ягідного, що виростає в Карпатах і Криму. Вказано про високий вміст 
SSP Modern Pharmacy and Medicine (ISSN 2733-368X), Volume 2 Issue 1, Jan-Mar 2022 таксанів у вітчизняній сировині та було запропоновано в якості рослинної сировини для одержання таксанів використовувати «лапки» тису ягідного, що дозволить забезпечити фармацевтичну промисловість України вітчизняною рослинною сировиною для одержання таксанів без шкоди для популяції тису ягідного. Дерева відновляться після заготівлі «лапки» до наступного року [35].

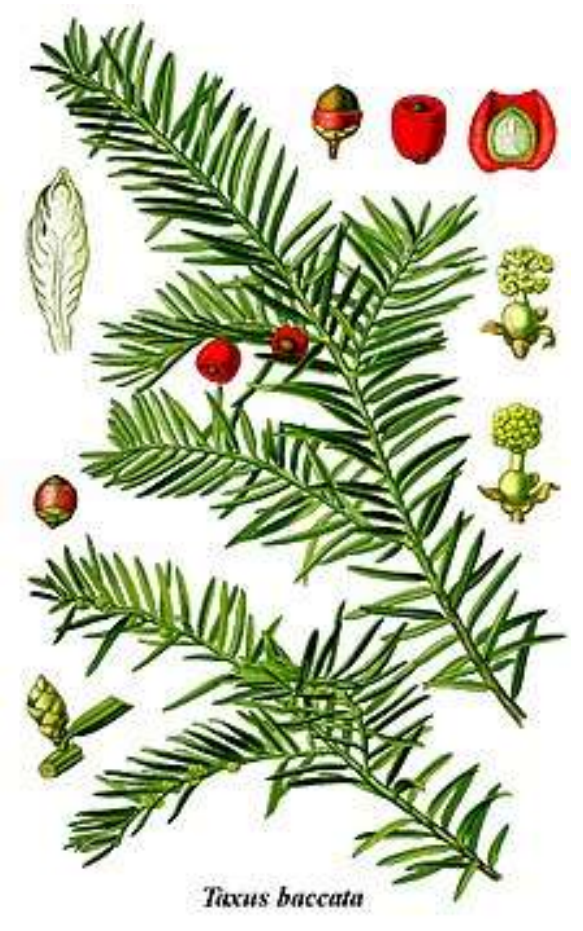

Рис. 1. Тис ягідний (Taxus baccata L.) [35].

Описано про фармакологічні дослідження таксанів, виділених 3 «лапки» тису ягідного. Результати показали високу протипухлинну активність відносно меланоми В-16, карциноми 757, саркоми 45 і карциноми Герена. Таксани $\epsilon$ одними 3 найбільш багатообіцяючих протипухлинних агентів, доступних сьогодні, і набувають все більшого значення в Азії, враховуючи, що рак в даний час є однією з основних проблем громадської охорони здоров'я, яку необхідно терміново вирішувати на благо хворих. Кілька поточних експериментальних i клінічних випробувань підтвердили той факт, що навіть з їх побічними ефектами і поганою розчинністю таксани як і раніше є першою лінією лікування, обраної для лікування раку грудей, яєчників, легенів та інших метастатичних пухлин [36, 37]. 
Продовження життя онкологічних хворих - головна мета всіх дослідників, вчених, фармацевтичних компаній та клініцистів; тому в цьому огляді підкреслюються механізми дії таксанів і те, яку важливу роль вони можуть відігравати в паліативному лікуванні, якщо вони не застосовуються в лікувальних цілях, тому вони вважаються перспективними у фармакотерапії раку. Компанія Daiichi Sankyo Co Ltd (раніше Daiichi Seiyaku CoLtd) розробила пероральний напівсинтетичний похідний таксану «tesetaxel» для потенційного лікування раку, включаючи рак прямої кишки і рак шлунку. Проте, в листопаді 2006 p. «tesetaxel» був виключений з процесу розробки Daiichi через недоведену ефективність для хіміотерапії раку [38].

За результатами огляду наукових джерел було встановлено про результати щодо розробки, доклінічних та клінічних випробувань потенційних протиракових агентів на основі дитерпеноїдного таксанового скелету. Протиракові властивості цього класу речовин через 13 років після використання в онкології паклітакселу (таксолу) показують, що базова структура таксану, як i раніше, використовується в якості вихідного каркасу для молекул з поліпшеними фармакологічними та токсикологічними властивостями. Фактично, паклітаксел може бути першим прикладом «настроєного» протиракового агента. Крім того, паклітаксел i, можливо, інші таксани мають активність, що виходить за рамки відомих протипухлинних показань, прикладом чого є використання стентів, покритих паклітакселом, в серцево-судинній терапії [39].

Доцетаксел (таксотер) $є$ ефективним засобом терапії при різних анатомічних локалізаціях пухлини i особливо при раку молочної залози. Таксотер входить в стандарти терапії метастатичного раку в ад'ювантному i неоад'ювантному режимах, як в комбінації з іншими цитостатиками, так і при поєднанні з анти-HER/2 агентами. Препарат не вимагає додаткових систем для інфузії, не підвищує кардіотоксичність доксорубіцину i не проявляє кумулятивної нейротоксичності. Економічна перевага препарату таксотер перед паклітакселом проявляється в його клінічній ефективності не при щотижневому застосуванні (паклітаксел), а при тритижневому режимі фармакотерапії [40]. 
Таким чином, результати огляду літератури свідчать про ефективність фармакотерапії операбельного раку молочної залози при включенні таксанів до складу ад'ювантної і неоад'ювантної хіміотерапії. Необхідно підкреслити, що вибір тактики лікування повинен завжди залежати від віку, загального стану, наявних симптомів і об'єктивних даних, прогностичних факторів (молекулярні підтипи), супутніх захворювань. Залежно від особливостей хвороби і стану пацієнтів таксани можна призначати як в поєднанні з антрациклінами (одночасно або послідовно), так і без них, в щотижневому і ущільненому режимах, в стандартних i високих дозах, а також в комплексі 3 гормонотерапією, герцептином, лапатінібом, авастином і іншими хіміопрепаратами і таргетними агентами [41]. Результати огляду наукової літератури було використано в навчальному процесі додипломної та післядипломної форми [42].

Висновки. Вивчено лікарські фітопрепарати для онкології на основі таксанів, протипухлинних дитерпенів Taxus Baccata L. в межах доказової фармації. Встановлено, що таксани вважаються перспективними у фармакотерапії раку. Описано про фармакологічні дослідження таксанів, які виділені 3 «лапки» тису ягідного. За результатами огляду наукових джерел встановлено про результати розробки, доклінічних та клінічних випробувань потенційних протиракових агентів на основі дитерпеноїдного таксанового скелету. Результати огляду літератури свідчать про перспективність включенні таксанів до складу ад'ювантної і неоад'ювантної хіміотерапії.

Конфлікт інтересів. Автори засвідчують, що не мають конфлікту інтересів та/або конкуруючих інтересів.

Фінансування. Автори засвідчують, що жодний фонд або агентство не фінансували це дослідження.

\section{Література.}

1. Shapovalova V.O., Zbrozhek S.I., Shapovalov V.V. et al. Coronavirus disease pandemia 2019: growth of epidemic dangers. Acta scientific pharmaceutical sciences. 2020. Vol. 4. Issue 7. P. 61-68. 
SSP Modern Pharmacy and Medicine (ISSN 2733-368X), Volume 2 Issue 1, Jan-Mar 2022

2. Shapovalov V., Butko L., Shapovalov V. Organizational and legal study of quarantine restrictions in the spread of coronavirus disease in Ukraine. SSP Modern Pharmacy and Medicine. 2021. Vol. 1. N. 2. P. 1-12. URL: https://doi.org/10.53933/sspmpm.v1i2.23.

3. Zbrozhek S. Reform of the healthcare system as a basis for streamlining the organization of circulation and availability of medicines for patients in the context of the COVID-19 pandemic. SSP Modern Pharmacy and Medicine. 2021. Vol. 1. No. 2. P. 1-32. URL: https://doi.org/10.53933/sspmpm.v1i2.31.

4. Shapovalov V. (Jr.), Zbrozhek S., Gudzenko A. et al. Organizational and legal analysis of the pharmaceutical provision for the most common diseases of society. International Journal of Pharmaceutical Sciences Review and Research. 2018. Vol. 51. N. 1. P. 118-124. URL: http://globalresearchonline.net/journalcontents/v511/18.pdf.

5. Shapovalova V.A., Zbrozhek S.I., Shapovalov V.V. et al. Forensic pharmacy: some risk factors in the formation of addictive health disorders. Acta Scientific Pharmaceutical Science. 2021. V. 4. Iss. 1. P. 7-12. DOI: 10.3180/ASPS.2020.05.0651.

6. Hayduchok I.G., Shapovalova V.O., Ishcheikin K.E. et al. Pharmacoeconomic approaches for pharmacotherapy of Rheumatoid arthritis. Likars'ka Sprava. 2021. N. 1-2. P. 54-63. DOI 10.31640/JVD.1-2.2021(8).

7. Grytsyk A., Gnatoyko K. Characteristics of plants of the Genus eryngium and prospects of their use in medicine. SSP Modern Pharmacy and Medicine. 2021. Vol.1. N.2. P.1-8. URL:https://doi.org/10.53933/sspmpm.v1i2.27.

8. Derkach A., Butko A., Nehretskii S. Evidence-based pharmacy: obtaining and studying of aescine from the plant of aesculus hippocastanum. SSP Modern Pharmacy and Medicine. 2021. Vol. 1. N.1. P. 1-7. URL: https://doi.org/10.53933/sspmpm.v1i1.10.

9. Grytsyk A., Struk O., Stasiv T. Investigation of acute toxicity and hepaprotective effect of extracts of Nepeta cataria L. Actual Problems of Medicine and Pharmacy. 2021.

Vol.

1.

N.

$1-2$.

Retrieved

from 

https://apmplmi.com/index.php/apmp/article/view/22.

10. Grytsyk A., Dubel N., Grytsyk L. Research of extraction parameters of Alchemilla subcrenata bus. Herb. SSP Modern Pharmacy and Medicine. 2021. Vol.1. N.2. P. 1-9. URL: https://doi.org/10.53933/sspmpm.v1i2.28.

11. Invitation to the XVIII Multidisciplinary Scientific and Practical Conference with International Participation "Medical and Pharmaceutical Law of Ukraine: Organization of Pharmaceutical Business, Technology, Pharmaceutical Analysis and Pharmacology of Medicines, Forensic Pharmacy", which will be held on November 18-19, 2021 (Ukrainian registration certificate No. 403 of 24.12.2020). Lviv Medical Institute LLC. 18.01.2021. URL:https://medinstytut.lviv.ua/konferentsiya-med-i-farmpravol

12. XI Congress of Oncologists summed up its work. Oncology.ru. 21.05.2021. URL: http://www.oncology.ru/news/2021/05/21/.

13. Shapovalov V.V. (Jr.), Zbrozhek S.I., Shapovalova V.O. et al. Organizational and legal evaluation of availability of medicines' circulation for cancer patients Pharmacia. 2018. Vol. 65. N. 2. P. 17-22. URL: http://bsphs.org/?magasine=organizational-and-legal-evaluation-of-availability-ofmedicines-circulation-for-cancer-patients.

14. Oncology in Ukraine: incidence and mortality rates in 2019-2020. Analytical portal "Slovo $i$ dilo". 14.05.2021. URL: https://ru.slovoidilo.ua/2021/05/14/infografika/obshhestvo/onkologiya-ukraineuroven-zabolevaemosti-i-smertnosti-2019-2020-godax.

15. Cancer in 2020: 19.3 million new cases and 10 million deaths. UN.15.12.2020. URL: https://news.un.org/ru/story/2020/12/1392562.

16. National Strategy for Cancer Control until 2030. Ministry of Health of Ukraine. 12.02.2020. URL: https://moz.gov.ua/article/news/nacionalna-strategija-kontroljuonkologichnih-zahvorjuvan-do-2030-roku.

17. Zbrozhek S.I., Shapovalov V.V. (Jr.), Tarasova I.V. et al. Study of the problem of availability of narcotic analgesic drugs for cancer patients on the basis of pharmaceutical law. Collection of scientific works of NMAPE named after P.L. Shupyk. 

2017. Is. 28. P. 446-458.

18. Zbrozhek S.I., Shapovalova V.O., Shapovalov V.V. et al. Processing of the control regime of medicines for pharmacotherapy of chronic pain syndrome in the field of palliative aid. Likars'ka sprava. 2019. No 5-6. P.111-118. DOI: 10.31640/JVD.5-6. 19. Zbrozhek S.I., Shapovalova V.A., Shapovalov V.V. et al. Peculiarities of pharmaceutical provision of cancer patients with analgesic drugs in various countries of the world. Pharmacy of Kazakhstan. 2017. No. 1. pp. 18-24.

20. Shapovalova V.O. Creation of children dosage forms on the basis of known pharmacological substances: author's ref. dis. for degree of doctor of pharmaceutical sciences. Science: special. 15.00.04 "Organization and economics of pharmacy", 15.00.01 "Technology of drugs". Kharkiv, 1996. 46 p.

21. The system of developing antitumor preparation in the USSR and USA / End by N.N. Blokliin (USSR) and C.G. Lubrod (USA) joint USSR-USA edition: "Meditsina". 1977. $352 \mathrm{p}$.

22. Blokhin N.N., Perevodchikova N.I. Chemotherapy of tumors. USSR Academy of Medical Sciences. M.: Meditsina, 1984. 304 s.

23. Combined and complex treatment of patients with malignant tumors. Guide for physicians / Under ed. of V.I. Chisov, M.: Medicine, 1989. 560 p.

24. Brogden J.M. Nevidjon B. Vinorelbine tirtrate (Navelbine): drug profile and nursing implications of a new vinca alkaloid. Oncology Nursing Forum. 1995. Vol. 22. N. 4. P. $635-646$.

25. Tliigpen J.T., Vance R., Puneky L. et al. Chemotherapy as a palliative treatment in carcinoma of tlie uterine cervix. Seminars in Oncology. 1995. Vol. 22. N. 2. P. 1624.

26. Kawaliara M. Pliase III studies of combined chemotherapy and radiation in locally advanced non-small-cell lung cancer and limited small-cell lung cancer. Journal of Cancer \& Chemotherapy. 1995. Vol. 20. N. 3. P. 335-40.

27. Toso C., Lindley C. Vinorelbine: a novel vinca alkaloid. American Journal of Health-System Pharmacy. 1995. Vol. 52. N. 12. P. 1287-304.

28. Mottet Auselo N., Bons-Rosset F., Pellae-Cosset B. et al. Carboplatin and 
SSP Modern Pharmacy and Medicine (ISSN 2733-368X), Volume 2 Issue 1, Jan-Mar 2022 urothelial tumors: review of the literature. Bulletin du Cancer. 1995. Vol. 82. N. 3. P. 181-188.

29. Huizing M. T., Misservh Pieters R. C. et. all. Taxaiu-s: a new class oil antitumor agents. Cancer Investigation. 1995. Vol. 13. N. 4. P. 381-404.

30. Bunn P. A. Ir., Kelly K. New treatment agents for advanced small cell and nonsmall cell lung cancer. Source Seminars in Oncology. 1995. Vol. 22. N. 3. P. 53-63.

31. Bitton R.J., Figg W.D., Reed E.A. Pidiminary risk-benefit assessment of paclitaxel. Drug Safety. 1995. Vol. 12. N. 3. P. 196-208.

32. Lorigan P., Lee S.M., Betticher D. et. all. Chemotherapy with vincristine fosfamide, carboplatin, etoposide in small cell lung cancer. Seminars in Oncology. 1995. Vol. 22. N. 3. P. 32-41.

33. Lavelle F. Bissery M.C., Combeau Z. et. all. Preclinical evaluation of docetaxel (Taxotere). Seminars in Oncology. 1995. Vol. 22. N. 2. P. 3-16.

34. Fossella F.V., Lee J.S., Berillc J. Summary of phase II data of docetaxel (Taxotere), an active agent in (lie list- and second-line treatment or advanced non-small cell lung cancer. Source Seminars in Oncology. 1995. Vol. 22. N. 2. P. 22-29.

35. Taxus Baccata. Material from Wikipedia. URL: https://en.wikipedia.org/wiki/Taxus_baccata.

36. Tekol Y. The medieval physician Avicenna used an herbal calcium channel blocker, Taxus baccata L. Phytotherapy Research. 2007. Vol. 21, N. 7. P. 701-702.

37. Jasmine N., Fauzee S. Taxanes: promising anti-cancer drugs. Asian Pac. J. Cancer Prev. 2011. Vol.12. N.4. P. 837-51. URL: https://pubmed.ncbi.nlm.nih.gov/21790213/.

38. Roche M., Kyriakou H., Seiden M. Drug evaluation: tesetaxel--an oral semisynthetic taxane derivative. Curr Opin Investig Drugs. 2006. Vol. 7. N. 12. P. 1092-1099. URL: https://pubmed.ncbi.nlm.nih.gov/17209527/.

39. Kingston G. I, Newman D. J. Taxoids: cancer-fighting compounds from nature. Curr Opin Drug Discov Devel. 2007. Vol. 10. N. 2. P.130-144. URL: https://pubmed.ncbi.nlm.nih.gov/17436548/.

40. Kovalev A.A. Taxanes in chemotherapy for breast cancer. Specialized medical 

portal. 21.10.2017. URL:https://health-ua.com/article/31337-taksany-v-himioterapiiraka-molochnojzhelezy.

41. Limareva S.V. Taxanes in adjuvant and neoadjuvant therapy of breast cancer. Tumors of the female reproductive system. 2010. N. 4. P. 15-23. URL: https://doi.org/10.17650/1994-4098-2010-0-4-15-23.

42. Shapovalova V.O., Shapovalov V.V., Negretsky S.M. et al. Certificate of registration of copyright to the work. Ukraine. No. 107818. Textbook for undergraduate and postgraduate forms of education "Collection of test tasks". (Registration date 06.09.2021). Application c202105954 dated 25.08.2021. 